\title{
Corruption factor in the use of allocated funds for the development of animal husbandry
}

\author{
Victoria Kirilenko, ${ }^{1, *}$ \\ ${ }^{1}$ Institute of Service and Entrepreneurship (branch) of DSTU in Shakhty, 147 Shevchenko str., \\ Shakhty, 346500 Rostov region, Russia
}

\begin{abstract}
Agricultural cooperatives are seen as an efficient way for smallholder farmers to create bargaining power in order to achieve poverty reduction and food security. However, the success of these cooperatives depends on their ability to maintain their social capital, which is at the core of collective action. Using unique data collected from 511 agricultural cooperatives in 12 districts of Tigray region in northern Ethiopia, this paper examines the effects of cooperative size on conflict, fraud, and distrust. We used instrumental variables (IV) probit estimation techniques, accounting for endogeneity of membership size, to confirm that cooperative size does affect the occurrence of conflict, fraud, and trust. The results also indicate that other influencing factors include: cooperative age, number of employees, payment of dividends based on transaction volume, and heterogeneity of member goals.
\end{abstract}

\section{Introduction}

There is a problem of ensuring food security of the population and maximum independence of the country in this matter at the present stage of development of our country as well as any state. The work of the country's agro-industrial complex is aimed at solving this problem including all its components. The agro-industrial complex (AIC) is the largest intersectoral complex which includes several branches of the economy that ensure the production and processing of agricultural raw materials in order to obtain products that are brought to the final consumer.

The purpose of this work is to study the problem of criminal use of allocated funds for the development of animal husbandry and agricultural equipment.

The subject of the study is food security as well as farming, regulatory legal acts regulating these relations, as well as the practice of their application.

\section{Methodology}

\footnotetext{
*Corresponding author: shpigunova96@mail.ru
} 
The method of analysis and synthesis is used when writing an educational and research work. At first we analyze disparate legal and literary sources, information from which is synthesized to draw conclusions and form hypotheses.

\section{Results of the research}

Before we propose a way to ensure accounting, which will help to reduce such situations, we will understand the mechanism of crimes in the field of animal husbandry. As a rule, such crimes are crimes under Article 159.2 of the Criminal Code of the Russian Federation ("Fraud in receiving payments») 41. Next, we will discuss the features of characteristic illegal acts such as: illegal receipt of grants, subsidies, subventions allocated for the creation and reconstruction of livestock farms; development of breeding in animal husbandry; purchase of cattle, necessary agricultural equipment. That is, financial support for all those industries that include the agro-industrial complex as a whole. In general, the mechanism of committing offenses and (or) crimes can be considered as follows. The subject of the crime collects a package of necessary documents, which contains deliberately false information about certain circumstances (depending on the type of payment for which he claims). These documents are submitted to the body authorized to make a decision on the implementation of the payment, in this case, it depends on the level of the budget from which the funds will be allocated, in which their completeness and correctness of filling are checked. At the same time, the compliance of the declared content of the documents with the actual circumstances of the subject's activity is checked formally or not properly [10].

Table 1. Stages of animal husbandry development

\section{The domestication of wild animals}

Reproduction of animals under conditions of domestication

Improving the productivity and breeding qualities of animals

After that, if the documents are filled out correctly and there is a complete set of them, the budget funds are transferred to the current account of the person who uses them at his discretion. Since this mechanism manifests itself in a documentary form, the person who allegedly committed the crime is already known at the stage of verification measures. In connection with the crime, and it is the intent of the perpetrator, which must be proven, that is important subjective attitude of the defendant to the crime. The analysis of such criminal cases shows that when proving the most important and difficult point is the establishment of direct intent to steal already when processing documents for receiving the allocated funds and the lack of desire to fulfill their obligations. A mandatory element of proof is the seizure and attachment to the case of documents that served as a means of committing a crime. After the initiation of a criminal case, it is necessary to conduct active investigative actions as soon as possible. Especially, in our opinion, they should be focused on actually existing livestock facilities, and these actions should be conducted in conjunction with documentary evidence of the presence of mismatches between the existing person objects livestock and actually submitted documents must also scheduled and conducted forensic: forensic accounting and technical and forensic examination of documents [1].

The main circumstance, in our opinion, the perpetration of these crimes is low or inadequate quality inspections divisions of APK of documents submitted by applicants to obtain the corresponding budgetary payments, reduced inspection only documentary information on the accuracy and the list. The actual correspondence of the data to the real situation is not made or is not made in a proper manner, In addition to the investigation, in these cases it is necessary to establish such circumstances as: whether the unfair attitude of officials to their duties was not the result of receiving a bribe or negligent attitude. 42 After 
finding out these circumstances, it is necessary to respond in the prescribed manner by making representations about the elimination of the identified causes and conditions [2].

Taking into account the constantly changing conditions in the country and the world, it is necessary to ensure the smooth operation of the agro-industrial complex, which would give the maximum return when investing money in it. Accounting statements are the final stage of the accounting process. It is a set of reliable information and indicators about the activities of an economic entity for a certain period of time, grouped in the established order and sequence. The purpose of reporting in our case is to group accounting information and present it to interested users - bodies that provide funds for the development of the agro-industrial complex.43 In order to provide the most complete information from agribusiness entities, in our opinion, it is necessary that these participants use integrated reporting in their reporting activities, which differs from financial statements in that it contains, along with financial, and non-financial information [3].

The main purpose of integrated reporting is to show the value creation of an organization over a certain period. This form of reporting will allow regulatory authorities to monitor the real state of affairs at agricultural enterprises, especially when providing funds for their development. However, it is worth noting that another factor that could significantly affect the picture of what is happening in the field of allocation of funds is the mechanism itself for verifying information about the activities of enterprises.

\section{Discussion of results}

We mention above the state is interested in developing its own agricultural production, independent of external factors which could produce a sufficient number of high-quality products for its citizens, as well as be competitive on the world stage, which would give additional income to the state treasury. To implement this task it is necessary to provide domestic manufacturers with modern technologies with maximum productivity at a minimum of costs. This proposal can be implemented only with financial support, both from own funds and financing from outside [4].

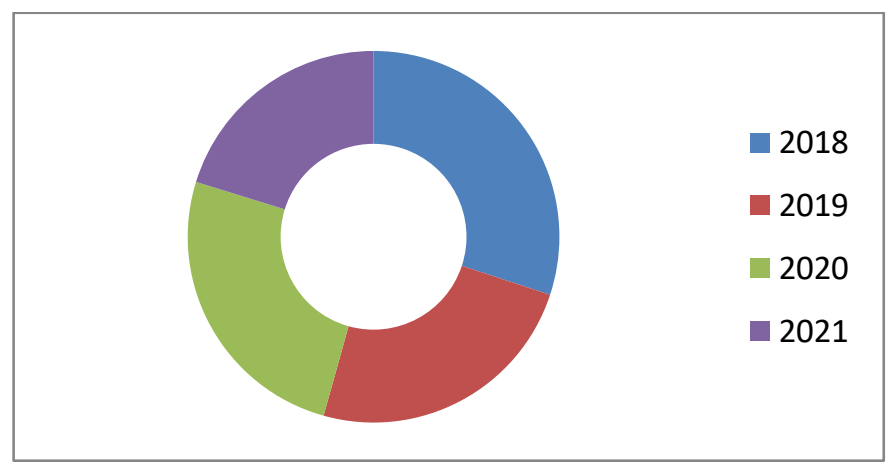

Fig. 1. Funds for the development of animal husbandry

Such a sphere of human activity as animal husbandry requires high costs, in addition, they are associated with risks, upon the occurrence of which producers may cease to exist in the market altogether, and this in turn can lead to both a direct reduction in the product produced and interruptions in food supplies, as well as many socio-economic problems, such as unemployment, capital outflow, etc. The state, fully aware of the possibility of such a scenario, provides support to the subjects of agricultural production, both directly, by providing funds the total amount of financial support for the "State Program for the Development of Agriculture and Regulation of Markets for Agricultural Products, Raw 
Materials and Food for 2013-2020" is 2220776191 thousand rubles, and indirectly, by providing various benefits, including tax.39 Also, various programs are being developed for the development of the agro-industrial complex as a whole, in particular its individual elements, various laws and bylaws are being adopted. They, in turn, establish the legal and economic basis for the priority of the agro-industrial complex in providing material and technical resources, ensuring the protection of the interests of the enterprises of the agroindustrial complex in the Russian Federation [5].

An example is the current Law of the Russian Federation" On priority provision of the agro-industrial complex with material and technical resources " dated 26.06.1991, No. 1490140. However, it should be noted that a simple allocation of funds, no matter how large their size may be, will not be able to ensure the normal, and even more so the progressive development of agriculture without proper control over the provided funds and their intended use, but this is not all, it is important that funding goes to really developing projects that provide an increase in agricultural products. That is, it is necessary to allocate funds not just to bona fide participants in agricultural production, but also to successful, knowledgeable individuals [9]. Contradictory and inconsistent state economic reforms have led to the strongest criminalization of the agro-industrial complex system. Crimes in this area contribute to the outflow of funds from the legal economy to the "shadow" economy, deprive the budgets of the state as a whole and the regions of part of an important income item. At present, in order to implement the above, the accounting system should come to the aid of the state. Currently, it suffers from unscrupulous producers who fraudulently try to get money for development, but after receiving it, they spend it on their own, non-agricultural purposes [6].

So the Central district court of Tver considered the criminal case against Popov G. V., accused of committing three crimes under part 3 of article 159 of the criminal code; part 4 of article 159, part 3 of article 30 of part 4 of article 159 of the criminal code.

Popov G. V. is accused of committing three crimes under Part 3 of Article 159 of the Criminal Code of the Russian Federation. In 2012, the state registration of a peasant (farmer) farm without the formation of a legal entity was carried out, the head of which is an individual entrepreneur Popov G. V.

The main type of economic activity of IP KFH Popov G. V. was the production of dairy products. Additional activities include: the cultivation of leguminous crops, growing vegetables, growing fiber spinning of crops, raising of other cattle, buffaloes, sheep, goats, pigs, providing services in crop production.

Since 2013 the Tver Region has provided state support to agricultural producers within the framework of the state program of the Tver Region "Agriculture of the Tver Region" for 2013-2018, approved by the Decree of the Government of the Tver Region of October 16, 2012 No. 608-pp "On the state program of the Tver Region "Agriculture of the Tver Region" for 2013-2018", the main administrator of which was the Ministry of Agriculture of the Tver Region [7].

The purpose of the program was to increase the competitiveness of the products of the agro-industrial complex of the Tver region in the domestic market, sustainable development of rural areas.

Subsidies have been granted in order to recover part of the cost of a complex of agrotechnical works, raising the level of environmental safety of agricultural production, improve the fertility and quality of soil per 1 hectare of sown area of agricultural crops in accordance with the area under the Agreement and in the order of the documents are subordinate to the Ministry of state public institution of the Tver region "Center of development of agroindustrial complex of the Tver region" or something gku "Center of development of agriculture in the Tver region»), based on the date and registration number of the submission of the complete set of documents by agricultural producers. 
According to the first episode, Popov G. V. committed fraud, that is, theft of other people's property by deception, on a large scale [8].

The defendants in the State Institution "Center for the Development of the Agro-industrial Complex of the Tver region" were presented with documents containing deliberately false and unreliable information about the estimated volumes of crops, which in reality he did not intend to carry out.

Taking into account the documents submitted by the Ministry of Agriculture of the Tver region, the funds of subsidies totaling 636,100 rubles were transferred to the settlement account of Popov G. V.

The received funds Popov G. V. stole and disposed of them in accordance with the criminal plan at his discretion [11].

$\mathrm{He}$ is in possession of information that the rates of subsidies per 1 ha of sown area increased significantly and knowing that I played and did not intend to fulfill its responsibility for the sowing of crops, appealed to gku "Center of development of agriculture of the Tver region", a statement of the additional subsidies in connection with the increase in rates.

On the basis of the submitted documents, the funds of subsidies totaling 341,700 rubles were transferred to the settlement account of IP GKFH Popov G. V..

In total, the Ministry of Agriculture transferred 977,800 rubles to the settlement account of G. V. Popov.

According to the second episode, Popov G. V. committed fraud, that is, theft of other people's property by deception, on a large scale.

IP GKFH Popov G. V., realizing their criminal intentions, personally signed an application for subsidies to support dairy cattle breeding, attaching documents containing knowingly false and unreliable information about the purchase of equipment, machines and mechanisms for dairy cattle breeding, namely, the purchase of a closed-type cooling tank, milking machines in the amount of 6 units, a milking unit, a vacuum pump, a pipe, a washing post, a water heater, two milking units, drinkers in the amount of 100 units, pasteurizer, electric shepherds in the amount of 4 units [12].

In the above equipment, Popov G. V. is not acquired, the information that the information is false and inaccurate, by authorized employees of gku THE "Center of development of agriculture of the Tver region" IP GCPH Popov G. V. deliberately concealed by tricking them that way.

Taking into account the documents submitted by IP GKFH Popov G. V., funds in the amount of 349,750. 06 rubles were transferred to the defendant's settlement account.

According to the third episode, Popov G. V. committed fraud, that is, theft of other people's property by deception, on a large scale.

Popov G. V., realizing his criminal intent aimed at embezzling budget funds, while receiving payments in the form of subsidies in a large amount by providing deliberately false and unreliable information for the purpose of illegal enrichment, appealed to the GKU TO "Center for the Development of the Agro-Industrial Complex of the Tver region" with an application for subsidies for purchased machine-building products from the regional budget for 2014 [13].

To the specified statement of SP GKFH Popov G. V. attached documents containing deliberately false and unreliable information about the purchase of a rotary rake GVR-630, a mower KSL-2.1 M, a plow PLN 3 - 35U with pre-lugs, a loader mounted PSN, a baler PRF145, a baler PRF-180, a forage harvester KDS-2.0, a disk mower KDP - 310-2, a tractor "Belarus 320.4". At the same time, in fact, the above-mentioned equipment and equipment were not purchased by the defendants.

Taking into account the documents submitted by IP GKFH Popov G. V. for granting a subsidy for the machine-building products purchased in 2014 from the regional budget, he was granted a subsidy in the amount of 267,677 rubles. 
He is also accused of committing fraud, that is, stealing someone else's property by deception on a particularly large scale.

Popov G. V., who was reliably aware of the provisions of the Procedure for providing unrelated Support to agricultural producers in the field of crop production, had a criminal intent aimed at committing fraud when receiving payments under this Procedure in a particularly large amount.

The defendant, realizing his criminal intent, aimed at the theft of budget funds upon receipt of payment in the form of subsidies in especially large size, wanting to earn income without any actual work, signed a statement on the provision of subsidies for the provision of support to agricultural producers in the field of plant from the regional and Federal budget for 2015 and submitted it to THE gku "Center of development of agriculture of Tver oblast" [14].

To the statement of IP GKFH Popov G. V. attached information about the settlement account opened by him for carrying out business activities, a certificate of a comprehensive and agrochemical and environmental survey of the land belonging to him, information about the results of sowing for the harvest of 2014, information about the size of the total sown area of agricultural crops in the reporting and current year, in which he personally indicated that the size of the total sown area on which he sowed in 2014 was 1,303 hectares, in 2015-1,375 hectares and the specified areas are located on the territory of the Firovsky district of the Tver region, and references-calculations for the provision of unrelated support to agricultural producers in the field of crop production for 2015, broken down by budget, according to which SP GKFH Popov G. V. personally indicated that they will be sown grain and leguminous crops on an area of 310 hectares, potatoes on an area of 10 hectares, flax on an area of 70 hectares, annual grasses and fodder crops on an area of 980 hectares [15].

This is actually to perform its obligations Popov G. V. is not intended to, information about what the facts are false and inaccurate, by authorized employees of gku THE "Center of development of agriculture of the Tver region" deliberately concealed by tricking them that way.

To the account Popov G. V. from the regional budget was transferred funds in the amount of 519700 rubles from the Federal budget in the amount of 855400 rubles, all transferred funds totaling 1100375 rubles

After that, knowing for certain that the subsidy rates for 1 hectare of sown area increased, the defendant applied to the State Institution "Center for the Development of the AgroIndustrial Complex of the Tver Region"for additional subsidies.

Taking into account the documents submitted by IP GKFH Popov G. V. for providing unrelated support to agricultural producers in the field of crop production for 2015, funds in the amount of 164,960 rubles were transferred to the settlement account.

He also committed an attempted crime, that is, intentional actions of a person directly aimed at committing fraud, that is, stealing someone else's property by deception on a particularly large scale, while the crime was not brought to an end due to circumstances beyond the control of this person.

Realizing criminal intentions Popov G. V. who reliably knew the conditions of the regional target program "Development of family livestock farms on the basis of peasant (farm) farms of the Tver region for 2015-2017", out of selfish motives, who wanted to receive income without any actual labor costs, produced a business plan and an expense plan, without which it was impossible for him to become a participant in this program, in which he indicated deliberately false and unreliable information about, that in addition to the budget funds in the amount of 5,024,000 rubles, they will attract their own and borrowed funds, which will be used for the reconstruction of the farm.

After receiving necessary for participation in the tender documents, IP GCPH Popov G. $\mathrm{V}$., provided the Ministry of agriculture of Tver region, the application for participation in 
the competitive selection of participants and the necessary documents confirming compliance with the requirements to the participants of the program.

At the same time G. V. Popov did not intend to actually fulfill his obligations, and he deliberately concealed the information that the information provided by him was deliberately false and unreliable from the authorized employees of the Ministry of Agriculture of the Tver Region, deceiving them in this way.

The competition commission for the selection of participants in regional target programs of the Ministry of Agriculture of the Tver region opened envelopes with applications, including the application of IP GKFH Popov G. V., after which it was found that the set of documents Popov G. V. does not contain mandatory documents, namely: documents confirming kinship relations for members of the peasant farm Popov G. V., a document confirming the ownership of livestock premises subject to reconstruction (modernization) in accordance with the Grant spending plan.

In connection with violations of the provisions of the List of documents approved by the Decree of the Government of the Tver region of June 26, 2012 No. 361-pp, the members of the competition commission decided not to consider the application submitted by IP GKFH Popov G. V.

Popov G. V. without abandoning the implementation of his criminal plan, repeatedly applied for participation in the competitive selection of participants in the regional target program "Development of family livestock farms on the basis of peasant (farm) farms of the Tver region for 2015-2017", in which he indicated the amount of budget funding in the amount of 8,659,000 rubles.

The competition commission for the selection of participants in regional target programs of the Ministry of Agriculture of the Tver Region found that the set of documents again lacked a mandatory document confirming the ownership of livestock premises subject to reconstruction (modernization) in accordance with the Grant spending plan, and therefore, the competition commission decided that it was impossible to recognize Popov G. V. as a participant in the Program.

After that, Popov G. V., continuing the implementation of his criminal intentions, wanting to achieve the goal of embezzlement of budget funds, again initiated an appeal to the Ministry of Agriculture of the Tver Region with an application for participation in the Program, while increasing the amount of budget allocations in the application to 9,300,000 rubles.

The competition commission decided that it was impossible to recognize Popov G. V. as a participant in the Program

However, Popov G. V., not wanting to abandon the previously planned criminal plan, realizing the illegality of their actions and wanting the onset of socially dangerous consequences in the form of causing property damage to the Ministry of Agriculture of the Tver region, Popov G. V. He made adjustments to the business plan and the expenditure plan, in which he indicated that in addition to budget funds in the amount of 9,300,000 rubles, they would attract their own and borrowed funds in the amount of 11,165,000 rubles, as well as a letter stating that they would reconstruct a cowshed, a hay storage facility, a dairy processing plant, a slaughterhouse and a meat processing plant, and the construction of guest houses, which was not true. In fact, Popov G. V. did not intend to fulfill his obligations.

The competition commission for the selection of participants in regional target programs of the Ministry of Agriculture of the Tver region reviewed the documents provided by IP GKFH Popov G. V. and checked for their authenticity, as a result of which it was found that the documents contain false information.

On the basis of findings of fictitious provided Yip GCPH Popov G. V. of documents related to the competition Commission for the selection of participants of the regional target programs of the Ministry of agriculture of the Tver region decision about the inability to recognize PI GCPH Popov G. V. party Programs that are independent from Popov G. V. 
circumstances deprived him of the opportunity to acquire cash subsidies in the amount of 9 300000 .

At the hearing, Popov G. V. pleaded not guilty to the charge brought against him.

Analyzing the examined evidence, both individually and in its entirety, the court found proven the guilt of Popov G. V. in the commission of the above-described crimes.

The sentence of the Central district court of Tver on 05 September 2018 Popov G. V. convicted of three crimes under article 159 part 3 of the criminal code, the crime provided by article 159 part 4 of the criminal code, the crime provided by article 30 , part 3 of article 159 part 4 of the criminal code and sentenced him:

- under part 3 of Article 159 of the Criminal Code of the Russian Federation (on the episode of embezzlement of 977800 rubles) in the form of imprisonment for a period of 2 (two) years 9 (nine) months without a fine and without restriction of freedom;

- under part 3 of Article 159 of the Criminal Code of the Russian Federation (on the episode of embezzlement of 349,750. 06 rubles) in the form of imprisonment for a period of 2 (two) years 6 (six) months without a fine and without restriction of freedom;

- under part 3 of Article 159 of the Criminal Code of the Russian Federation (on the episode of theft of 267,677 rubles) in the form of imprisonment for a period of 2 (two) years 6 (six) months without a fine and without restriction of freedom;

- under Part 4 of Article 159 of the Criminal Code of the Russian Federation in the form of imprisonment for a period of 5 (five) years without a fine and without restriction of freedom;

- under part 3 of Article 30 of Part 4 of Article 159 of the Criminal Code of the Russian Federation in the form of imprisonment for a period of 4 (four) years without a fine and without restriction of freedom.

In accordance with Part 3 of Article 69 of the Criminal Code of the Russian Federation on the totality of crimes by partial addition of the assigned punishments, Popov G. V. was finally sentenced to imprisonment for a period of 7 (seven) years without a fine and without restriction of freedom, with serving the sentence in a correctional colony of general regime.

For the civil plaintiff, the Ministry of Agriculture of the Tver Region recognized the right to satisfy a civil claim with the transfer of the issue of the amount of compensation for a civil claim filed in the amount of 977,800 rubles for consideration in civil proceedings.

\section{Conclusions}

In our opinion the current legislation does not specify in what status a peasant farm should be created. Due to changes made over the years, citizens who want to create the economic entity may incorrectly register it. Thus, we propose to make changes at the legislative level to the Federal Law "On Peasant (Farm) Economy", namely, to introduce norms that will prescribe a clear algorithm of actions when creating a peasant (farm) economy. We also believe that the solution to the current problems related to the relationship between civil and land legislation in the regulation of transactions with land plots can be the official recognition of the intersectoral nature of this relationship, which will allow to resolve most of the legal conflicts between civil and land legislation, including in the case of transactions with different land plots.

The question of the relationship between civil and land legislation arising from the regulation of land relations can be completely removed, if the legislator will identify land and civil law to the objects of exclusive competence of the Russian Federation or to the joint jurisdiction of the Russian Federation and its constituent entities, which will also allow you to avoid all sorts of contradictions between the state and Federal laws governing civil and land relations. 


\section{References}

1. R. Paut, R. Sabatier, M. Tchamitchian, Reducing risk through crop diversification: an application of portfolio theory to diversified horticultural systems Agric. Syst. 168, 123130 (2019)

2. H.C. Norman, D.G. Masters, E.G. Barrett-Lennard, Halophytes as forages in saline landscapes: interactions between plant genotype and their environment change their feeding value to ruminants J. Exp. Environ. Bot. 92, 96-109 (2013)

3. L. Ruiz-Garcia, L. Lunadei, The role of rfid in agriculture: Applications, limitations and challenges Comput. Electron. Agric. 79(1), 42-50 (2011)

4. E. Poyatos-Racionero, J.V. Ros-Lis, J.-L. Vivancos, R. Martínez-Máñez, Recent advances on intelligent packaging as tools to reduce food waste J. Cleaner Prod. 172, 3398-3409 (2018)

5. R. Newsome, C.G. Balestrini, M.D. Baum, J. Corby, W. Fisher, K. Goodburn, T.P. Labuza, G. Prince, H.S. Thesmar, F. Yiannas, Applications and perceptions of date labeling of food Compr. Rev. Food Sci. Food Saf. 13(4), 745-769 (2014)

6. L. Karabarbounis, B. Neiman, The global decline of the labor share Q. J. Econ. 129(1), 61-103 (2014)

7. E.K. Owusu, A.P. Chan, M. Shan, Causal factors of corruption in construction project management: an overview Sci. Eng. Ethics 1-31 (2017)

8. G. Locatelli, G. Mariani, T. Sainati, M. Greco, Corruption in public projects and megaprojects: There is an elephant in the room! Int. J. Proj. Manag. 35(3), 252-268 (2017)

9. P.E. Eriksson, M. Westerberg, Effects of cooperative procurement procedures on construction project performance: a conceptual framework Int. J. Proj. Manag. 29(2), 197-208 (2011)

10. E.E. Ameyaw, A.P. Chan, D.G. Owusu-Manu, E. ColemanA fuzzy model for evaluating risk impacts on variability between contract sum and final account in government-funded construction projects J. Facil. Manag. 13(1), 45-69 (2015)

11. E.E. Ameyaw, A.P. Chan, A fuzzy approach for the allocation of risks in public-private partnership water-infrastructure projects in developing countries J. Infrastruct. Syst. 22(3) (2016)

12. M. Shan, B.G. Hwang, K.S.N. Wong, A preliminary investigation of underground residential buildings: advantages, disadvantages, and critical risks Tunn. Undergr. Space Technol. 70, 19-29 (2017)

13. M. Shan, A.P. Chan, Y. Le, Y. Hu Investigating the effectiveness of response strategies for vulnerabilities to corruption in the Chinese public construction sectorSci. Eng. Ethics 21(3), 683-705 (2015)

14. M.R. Hosseini, I. Martek, S. Banihashemi, A.P. Chan, A. Darko, M. Tahmasebi, Distinguishing characteristics of corruption risks in Iranian construction projects: a weighted correlation network analysis Sci. Eng. Ethics, 1-27 (2019)

15. F.L. Greitzer, L.J. Kangas, C.F. Noonan, C.R. Brown, T. FerrymanPsychosocial modeling of insider threat risk based on behavioral and word use analysis e Serv. J. 9(1), 106-138 (2013) 